(C) 2020 by the Arizona Board of Regents on behalf of the University of Arizona. This is an Open Access article, distributed under the terms of the Creative Commons Attribution licence (http://creativecommons. org/licenses/by/4.0/), which permits unrestricted re-use, distribution, and reproduction in any medium, provided the original work is properly cited.

\title{
ERRONEOUSLY OLD RADIOCARBON AGES FROM TERRESTRIAL POLLEN CONCENTRATES IN YELLOWSTONE LAKE, WYOMING, USA
}

\author{
Christopher M Schiller ${ }^{*}$ (i) $\cdot$ Cathy Whitlock ${ }^{1,2} \cdot$ Kathryn L Elder $^{3}$ (D) Nels A Iverson ${ }^{4} \cdot$ \\ Mark B Abbott ${ }^{5}$ \\ ${ }^{1}$ Montana State University, Department of Earth Sciences, Bozeman, MT 59717 USA \\ ${ }^{2}$ Montana State University, Montana Institute on Ecosystems, Bozeman, MT 59717 USA \\ ${ }^{3}$ Woods Hole Oceanographic Institution, Department of Geology and Geophysics, Woods Hole, MA 02543 USA \\ ${ }^{4}$ New Mexico Bureau of Geology and Mineral Resources, New Mexico Institute of Mining and Technology, Socorro, \\ NM 87801 USA \\ ${ }^{5}$ University of Pittsburgh, Department of Geology and Environmental Science, Pittsburgh, PA 15260 USA
}

\begin{abstract}
Accelerator mass spectrometry (AMS) dating of pollen concentrates is often used in lake sediment records where large, terrestrial plant remains are unavailable. Ages produced from chemically concentrated pollen as well as manually picked Pinaceae grains in Yellowstone Lake (Wyoming) sediments were consistently 1700 4300 cal years older than ages established by terrestrial plant remains, tephrochronology, and the age of the sediment-water interface. Previous studies have successfully utilized the same laboratory space and methods, suggesting the source of old-carbon contamination is specific to these samples. Manually picking pollen grains precludes admixture of non-pollen materials. Furthermore, no clear source of old pollen grains occurs on the deglaciated landscape, making reworking of old pollen grains unlikely. High volumes of $\mathrm{CO}_{2}$ are degassed in the Yellowstone Caldera, potentially introducing old carbon to pollen. While uptake of old $\mathrm{CO}_{2}$ through photosynthesis is minor $\left(\mathrm{F}^{14} \mathrm{C}\right.$ approximately 0.99$)$, old-carbon contamination may still take place in the water column or in surficial lake sediments. It remains unclear, however, what mechanism allows for the erroneous ages of highly refractory pollen grains while terrestrial plant remains were unaffected. In the absence of a satisfactory explanation for erroneously old radiocarbon ages from pollen concentrates, we propose steps for further study.
\end{abstract}

KEYWORDS: AMS dating, chronology, contamination, paleoecology, pine.

\section{INTRODUCTION}

Lake sediments are the primary archive for reconstructing late-Quaternary terrestrial climate, vegetation, fire, and limnobiotic processes. Correlation between sites and comparison of independent proxies and paleoclimate model simulations requires sedimentary records with high-resolution age-depth control, most commonly accomplished through radiocarbon dating. The utility of radiocarbon dating pollen concentrates with accelerator mass spectrometry (AMS) has been well established in lacustrine settings where terrestrial plant remains are unavailable and where total organic carbon of (bulk) sediments are potentially contaminated by refractory carbon and reservoir effects. Pollen concentration through mechanical separation (Brown et al. 1989; Long et al. 1992; Mensing and Southon 1999), chemical maceration (Doher 1980), heavy liquid separation (Vandergoes and Prior 2003), and flow cytometry (Tennant et al. 2013) selectively removes anachronous sources of carbon (e.g. carbonates, algal remains, humic acids) from the sample. Although some studies suggest dating errors as a result of incomplete separation of non-pollen material (Regnéll 1992; Richardson and Hall 1994) or incorporation of reworked pollen grains (Mensing and Southon 1999; Zimmerman et al. 2019), pollenconcentrate ages typically produce more reliable chronologies than bulk-sediment ages where reservoir effects are a concern (e.g. Brown et al. 1989; Vandergoes and Prior 2003; Newnham et al. 2007; Fletcher et al. 2017).

Yellowstone Lake, Wyoming $\left(44.5^{\circ} \mathrm{N}, 110.3^{\circ} \mathrm{W}\right.$, elev. 2360 m.a.s.1.), a large $\left(352 \mathrm{~km}^{2}\right)$, temperate, subalpine lake (Figure 1), is a good candidate for AMS dating of pollen

\footnotetext{
*Corresponding author. Email: christopher.schiller@student.montana.edu.
} 


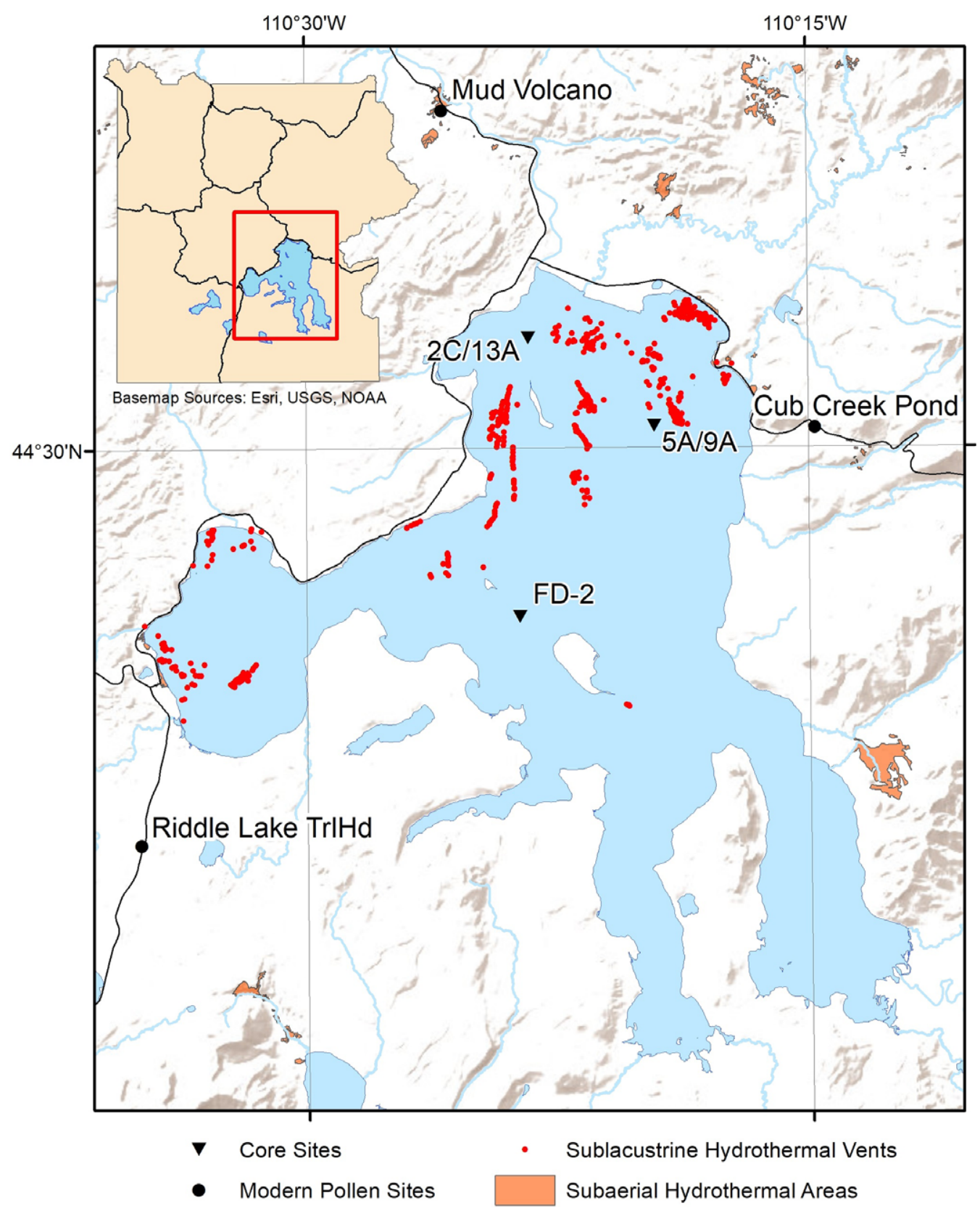

Figure 1 Map of the Yellowstone Lake basin, showing location of the collection of sediment cores and modern pollen samples. Subaerial hydrothermal areas based on Vaughan et al. (2014) and sublacustrine hydrothermal vents based on Morgan et al. (2007). All sites are located within or near the eastern half of the Yellowstone Caldera, where the majority of $\mathrm{CO}_{2}$ degassing occurs from acid-sulfate hydrothermal vents (Werner and Brantley 2003).

concentrates, as few sufficiently large, terrestrial plant remains were recovered from recent coring efforts (2016, Table 1). The geology of the watershed is complex, resulting from an interplay of volcanic, glacial, and hydrothermal processes. The northern two-thirds of the lake basin lies within the Yellowstone Caldera that was formed $630 \mathrm{ka}$ (Christiansen 2001; 
Table 1 Yellowstone Lake and vicinity age controls.

\begin{tabular}{|c|c|c|c|c|c|c|c|c|}
\hline $\begin{array}{l}\text { Accession } \\
\text { no. }{ }^{1} \\
\text { (receipt no.) }\end{array}$ & $\begin{array}{l}\text { Core depth }(\mathrm{cm})^{2} / \\
\text { location }\end{array}$ & Material dated $^{3}$ & $\begin{array}{c}\mathrm{C} \\
(\mu \mathrm{g})\end{array}$ & $\begin{array}{c}\delta^{13} \mathrm{C} \\
\% \text { VPDB }\end{array}$ & Age ${ }^{14} \mathrm{C}$ & $\mathrm{F}^{14} \mathrm{C}^{4}$ & $\begin{array}{l}2-\sigma \text { cal BP age range } \\
{\text { (probability })^{5}}^{\text {pol }}\end{array}$ & Source $^{6}$ \\
\hline \multicolumn{9}{|l|}{ FD-2 } \\
\hline C-5753 & 24.0 & t. plant remains & & & $430 \pm 70$ & $0.9479 \pm 0.0082$ & $\begin{array}{l}307-552(0.998) \\
614-616(0.002)\end{array}$ & Tiller 1995 \\
\hline C-5755 & 123.5 & t. plant remains & & & $1450 \pm 100$ & $0.8348 \pm 0.0103$ & 1179-1558 (1.000) & Tiller 1995 \\
\hline C-10034 & 225.5 & humic acid & & & $6060 \pm 60$ & $0.4703 \pm 0.0035$ & $\begin{array}{l}6750-6767(0.016) \\
6774-7030(0.879) \\
7043-7070(0.022) \\
7077-7086(0.008) \\
7097-7156(0.074)\end{array}$ & This work \\
\hline C-10035 & 225.5 & humin & & & $6030 \pm 60$ & $0.4721 \pm 0.0035$ & $\begin{array}{l}6698-6700(0.001) \\
6719-7022(0.977) \\
7120-7152(0.022)\end{array}$ & This work \\
\hline C-10048 & 295.5 & t. plant remains & & & $7950 \pm 180$ & $0.3717 \pm 0.0082$ & $8408-9289$ (1.000) & Tiller 1995 \\
\hline C-10037 & 295.5 & humic acid & & & $7740 \pm 60$ & $0.3815 \pm 0.0028$ & $\begin{array}{l}8410-8609(0.991) \\
8618-8626(0.009)\end{array}$ & This work \\
\hline C-10036 & 295.5 & humin & & & $7680 \pm 60$ & $0.3844 \pm 0.0029$ & $8389-8581$ (1.000) & This work \\
\hline C-5754 & 455.3 & t. plant remains & & & $9080 \pm 100$ & $0.3230 \pm 0.0040$ & $\begin{array}{c}9915-10098(0.149) \\
10110-10511(0.851)\end{array}$ & Tiller 1995 \\
\hline C-10039 & 475.5 & humic acid & & & $10460 \pm 80$ & $0.2720 \pm 0.0027$ & $12064-12596(1.000)$ & This work \\
\hline C-10040 & 475.5 & humin & & & $10280 \pm 60$ & $0.2781 \pm 0.0021$ & $\begin{array}{l}11815-12244(0.885) \\
12266-12383(0.115)\end{array}$ & This work \\
\hline C-4977 & 476.6 & t. plant remains & & & $6290 \pm 80$ & $0.4570 \pm 0.0045$ & $\begin{array}{l}7615-7879(0.924) \\
7890-7931(0.076)\end{array}$ & Tiller 1995 \\
\hline C-10038 & 505.5 & t. plant remains & & & $7100 \pm 210$ & $0.4132 \pm 0.0107$ & $7580-8340(1.000)$ & Tiller 1995 \\
\hline C-10047 & 505.5 & t. plant remains & & & $7060 \pm 100$ & $0.4152 \pm 0.0051$ & $\begin{array}{l}7673-8051(0.996) \\
8098-8102(0.001) \\
8144-8149(0.003)\end{array}$ & Tiller 1995 \\
\hline C-9165 & 505.5 & humic acid & & & $11380 \pm 80$ & $0.2425 \pm 0.0024$ & 13079-13386 (1.000) & This work \\
\hline C-9164 & 505.5 & humin & & & $10280 \pm 90$ & $0.2781 \pm 0.0031$ & $\begin{array}{l}11651-11662(0.003) \\
11705-12418(0.997)\end{array}$ & This work \\
\hline & 506.5 & Mazama ash & & & & & $7584-7682$ & $\begin{array}{l}\text { Egan et al. } \\
2015\end{array}$ \\
\hline C-4976 & 582.7 & t. plant remains & & & $8290 \pm 120$ & $0.3563 \pm 0.0053$ & $\begin{array}{l}9010-9503(0.997) \\
9511-9516(0.003)\end{array}$ & Tiller 1995 \\
\hline C-10042 & 582.5 & humic acid & & & $12350 \pm 80$ & $0.2149 \pm 0.0021$ & $14067-14830(1.000)$ & This work \\
\hline
\end{tabular}




\begin{tabular}{|c|c|c|c|c|c|c|c|c|}
\hline $\begin{array}{l}\text { Accession } \\
\text { no. }{ }^{1} \\
\text { (receipt no.) }\end{array}$ & $\begin{array}{c}\text { Core depth }(\mathrm{cm})^{2} / \\
\text { location }\end{array}$ & Material dated ${ }^{3}$ & $\begin{array}{c}\text { C } \\
(\mu \mathrm{g})\end{array}$ & $\begin{array}{c}\delta^{13} \mathrm{C} \\
\% \text { VPDB }\end{array}$ & Age ${ }^{14} \mathrm{C}$ & $\mathrm{F}^{14} \mathrm{C}^{4}$ & $\begin{array}{c}2-\sigma \text { cal BP age range } \\
\text { (probability })^{5}\end{array}$ & Source $^{6}$ \\
\hline C-10041 & 582.5 & humin & & & $12050 \pm 70$ & $0.2231 \pm 0.0019$ & $13748-14088(1.000)$ & This work \\
\hline C-4974 & 657.0 & t. plant remains & & & $10200 \pm 90$ & $0.2809 \pm 0.0031$ & $\begin{array}{l}11404-11568(0.067) \\
11573-11576(0.001) \\
11591-12189(0.901) \\
12199-12237(0.015) \\
12283-12301(0.006) \\
12343-12376(0.012)\end{array}$ & Tiller 1995 \\
\hline C-4973 & 735.1 & t. plant remains & & & $10280 \pm 80$ & $0.2781 \pm 0.0028$ & $11757-12401(1.000)$ & Tiller 1995 \\
\hline C-10044 & 766.5 & humic acid & & & $16850 \pm 60$ & $0.1228 \pm 0.0009$ & $20105-20523(1.000)$ & This work \\
\hline C-10043 & 766.5 & humin & & & $17090 \pm 150$ & $0.1191 \pm 0.0022$ & $20202-21013(1.000)$ & This work \\
\hline C-10046 & 778.3 & humic acid & & & $18240 \pm 100$ & $0.1032 \pm 0.0013$ & 21846-22366 (1.000) & This work \\
\hline C-10045 & 778.3 & humin & & & $17950 \pm 100$ & $0.1070 \pm 0.0013$ & $21432-22027(1.000)$ & This work \\
\hline C-9162 & 854.0 & humic acid & & & $16420 \pm 180$ & $0.1295 \pm 0.0029$ & 19359-20279 (1.000) & This work \\
\hline C-9163 & $\begin{array}{l}854.0 \\
855.0\end{array}$ & $\begin{array}{l}\text { humin } \\
\text { Glacier Peak } \\
\quad \text { (B or G) ash }\end{array}$ & & & $18900 \pm 250$ & $0.0951 \pm 0.0029$ & $\begin{array}{l}22309-23445(1.000) \\
13410-13710(1.000)\end{array}$ & $\begin{array}{l}\text { This work } \\
\text { Kuehn et al. } \\
2009\end{array}$ \\
\hline \multicolumn{9}{|l|}{ 13A } \\
\hline $\begin{array}{r}\text { OS-142012 } \\
(153942)\end{array}$ & 1.0 & bulk sediment & 1559 & & $5250 \pm 25$ & $0.5203 \pm 0.0017$ & $\begin{array}{l}5928-6026(0.729) \\
6047-6065(0.029) \\
6077-6116(0.160) \\
6152-6175(0.082)\end{array}$ & This work \\
\hline $\begin{array}{r}\text { OS-142223 } \\
(153938)\end{array}$ & 1.0 & picked pollen & 22 & & $2310 \pm 180$ & $0.7505 \pm 0.0164$ & $\begin{array}{l}1904-1907(0.001) \\
1924-2755(0.999)\end{array}$ & This work \\
\hline & 12.0 & $1700 \mathrm{CE}$ fire & & & & & $240-260$ & $\begin{array}{c}\text { Romme \& } \\
\text { Despain, } \\
1989\end{array}$ \\
\hline \multicolumn{9}{|l|}{$2 \mathrm{C}$} \\
\hline $\begin{array}{r}\text { OS-138757 } \\
(149875)\end{array}$ & 164.0 & c.c. pollen & 476 & & $3860 \pm 20$ & $0.6185 \pm 0.0016$ & $\begin{array}{l}4163-4166(0.006) \\
4181-4198(0.047) \\
4230-4407(0.948)\end{array}$ & This work \\
\hline $\begin{array}{r}\text { OS-135957 } \\
(147265)\end{array}$ & 328.0 & t. plant remains & 670 & -26.3 & $2590 \pm 20$ & $0.7242 \pm 0.0019$ & $2723-2754(1.000)$ & This work \\
\hline
\end{tabular}

$10280 \pm 80$

$17950 \pm 100$

$16420 \pm 180$

(B or G) ash
$0.2781+0.0028$

$0.1070 \pm 0.0013$

$0.1295 \pm 0.0029$

$0.0951 \pm 0.0029$

core top

bulk sediment

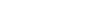


Table 1 (Continued)

\begin{tabular}{|c|c|c|c|c|c|c|c|c|}
\hline $\begin{array}{l}\text { Accession } \\
\text { no. }{ }^{1} \\
\text { (receipt no.) }\end{array}$ & $\begin{array}{l}\text { Core depth }(\mathrm{cm})^{2} / \\
\text { location }\end{array}$ & Material dated ${ }^{3}$ & $\begin{array}{c}\mathrm{C} \\
(\mu \mathrm{g})\end{array}$ & $\begin{array}{c}\delta^{13} \mathrm{C} \\
\% \text { VPDB }\end{array}$ & Age ${ }^{14} \mathrm{C}$ & $\mathrm{F}^{14} \mathrm{C}^{4}$ & $\begin{array}{l}2-\sigma \text { cal BP age range } \\
{\text { (probability })^{5}}^{\text {probat }}\end{array}$ & Source $^{6}$ \\
\hline $\begin{array}{r}\text { OS-135958 } \\
(147266)\end{array}$ & 402.0 & t. plant remains & 1130 & -28.0 & $3150 \pm 25$ & $0.6760 \pm 0.0022$ & $\begin{array}{l}3272-3285(0.038) \\
3339-3445(0.962)\end{array}$ & This work \\
\hline $\begin{array}{r}\text { OS-138692 } \\
(149876)\end{array}$ & 524.5 & c.c. pollen & 440 & & $6280 \pm 30$ & $0.4574 \pm 0.0017$ & $7164-7263(1.000)$ & This work \\
\hline $\begin{array}{r}\text { OS-136956 } \\
(147971)\end{array}$ & 624.0 & t. plant remains & 643 & & $4510 \pm 20$ & $0.5707 \pm 0.0016$ & $\begin{array}{l}5053-5190(0.688) \\
5213-5296(0.312)\end{array}$ & This work \\
\hline $\begin{array}{r}\text { OS-142084 } \\
(153943)\end{array}$ & 755.0 & t. plant remains & 148 & -10.9 & $9980 \pm 45$ & $0.2887 \pm 0.0017$ & $\begin{array}{l}11259-11623(0.985) \\
11675-11694(0.015)\end{array}$ & This work \\
\hline $\begin{array}{r}\text { OS-138693 } \\
(149877)\end{array}$ & 792.0 & c.c. pollen & 307 & & $7220 \pm 35$ & $0.4068 \pm 0.0018$ & $\begin{array}{l}7963-8072(0.764) \\
8085-8158(0.236)\end{array}$ & This work \\
\hline $\begin{array}{r}\text { OS-142082 } \\
(153939)\end{array}$ & 934.5 & bulk sediment & 461 & & $11150 \pm 55$ & $0.2497 \pm 0.0016$ & $12841-13112(1.000)$ & This work \\
\hline $\begin{array}{r}\text { OS-142018 } \\
(153935)\end{array}$ & 934.5 & picked pollen & 58 & & $10250 \pm 170$ & $0.2793 \pm 0.0059$ & $\begin{array}{l}11348-11380(0.011) \\
11386-12540(0.989)\end{array}$ & This work \\
\hline & 940.0 & Mazama ash & & & & & $7584-7682$ & $\begin{array}{l}\text { Egan et al., } \\
2015\end{array}$ \\
\hline $\begin{array}{r}\text { OS-138622 } \\
(149869)\end{array}$ & 965.5 & t. plant remains & 190 & & $5740 \pm 30$ & $0.4895 \pm 0.0019$ & $\begin{array}{l}6453-6459(0.012) \\
6462-6634(0.988)\end{array}$ & This work \\
\hline $\begin{array}{r}\text { OS-138700 } \\
(149878)\end{array}$ & 978.0 & c.c. pollen & 569 & & $9870 \pm 55$ & $0.2928 \pm 0.0019$ & $\begin{array}{l}11188-11405(0.982) \\
11457-11465(0.004) \\
11563-11593(0.014)\end{array}$ & This work \\
\hline $\begin{array}{r}\text { OS-138701 } \\
(149879)\end{array}$ & 986.0 & c.c. pollen & 248 & & $9390 \pm 50$ & $0.3106 \pm 0.0019$ & $10500-10741(1.000)$ & This work \\
\hline $\begin{array}{r}\text { OS-138866 } \\
(149880)\end{array}$ & 1160.5 & c.c. pollen & 545 & & $12100 \pm 110$ & $0.2215 \pm 0.0031$ & $\begin{array}{l}13639-13663(0.004) \\
13707-14303(0.996)\end{array}$ & This work \\
\hline $9 A$ & & oropton & & & & & & \\
\hline $\begin{array}{r}\text { OS-142011 } \\
(153941)\end{array}$ & $\begin{array}{c}0 \\
1.0\end{array}$ & $\begin{array}{l}\text { core top } \\
\text { bulk sediment }\end{array}$ & 2051 & & $4080 \pm 25$ & $0.6017 \pm 0.0019$ & $\begin{array}{c}-67 \\
4447-4470(0.060) \\
4516-4644(0.770) \\
4677-4692(0.017) \\
4761-4800(0.153)\end{array}$ & This work \\
\hline
\end{tabular}

(Continued) 
Table 1 (Continued)

\begin{tabular}{|c|c|c|c|c|c|c|c|c|}
\hline $\begin{array}{l}\text { Accession } \\
\text { no. }{ }^{1} \\
\text { (receipt no.) }\end{array}$ & $\begin{array}{l}\text { Core depth }(\mathrm{cm})^{2} / \\
\text { location }\end{array}$ & Material dated ${ }^{3}$ & $\begin{array}{c}\mathrm{C} \\
(\mu \mathrm{g})\end{array}$ & $\begin{array}{c}\delta^{13} \mathrm{C} \\
\% \text { VPDB }\end{array}$ & Age ${ }^{14} \mathrm{C}$ & $\mathrm{F}^{14} \mathrm{C}^{4}$ & $\begin{array}{c}2-\sigma \text { cal BP age range } \\
{\text { (probability })^{5}}^{\text {probat }}\end{array}$ & Source $^{6}$ \\
\hline $\begin{array}{r}\text { OS-142222 } \\
(153937)\end{array}$ & 1.0 & picked pollen & 34 & & $1910 \pm 110$ & $0.7885 \pm 0.0109$ & $\begin{array}{l}1571-1583(0.006) \\
1598-2120(0.994)\end{array}$ & This work \\
\hline $\mathbf{5 A}$ & & & & & & & & \\
\hline $\begin{array}{r}\text { OS-135959 } \\
(147267)\end{array}$ & 364.5 & t. plant remains & 730 & -27.1 & $3760 \pm 30$ & $0.6261 \pm 0.0022$ & $\begin{array}{l}3993-4039(0.127) \\
4074-4184(0.727) \\
4188-4192(0.007) \\
4195-4235(0.139)\end{array}$ & This work \\
\hline $\begin{array}{r}\text { OS-138998 } \\
(149881)\end{array}$ & 533.5 & c.c. pollen & 202 & -0.4 & $6140 \pm 95$ & $0.4654 \pm 0.0054$ & $6792-7254(1.000)$ & This work \\
\hline $\begin{array}{r}\text { OS-138868 } \\
(149882)\end{array}$ & 540.5 & c.c. pollen & 411 & & $6600 \pm 45$ & $0.4395 \pm 0.0024$ & $7433-7566(1.000)$ & This work \\
\hline $\begin{array}{r}\text { OS-142083 } \\
(153940)\end{array}$ & 782.0 & bulk sediment & 405 & & $11050 \pm 50$ & $0.2524 \pm 0.0016$ & 12779-13057 (1.000) & This work \\
\hline \multirow[t]{2}{*}{$\begin{array}{r}\text { OS-142221 } \\
(153936)\end{array}$} & 782.0 & picked pollen & 43 & & $5530 \pm 130$ & $0.5021 \pm 0.0083$ & $\begin{array}{l}5999-6568(0.977) \\
6586-6627(0.023)\end{array}$ & This work \\
\hline & 783.0 & Mazama ash & & & & & $7584-7682$ & $\begin{array}{l}\text { Egan et al., } \\
2015\end{array}$ \\
\hline $\begin{array}{r}\text { OS-139001 } \\
(149883)\end{array}$ & 814.0 & c.c. pollen & 243 & -25.5 & $9060 \pm 50$ & $0.3236 \pm 0.0021$ & $\begin{array}{l}10157-10299(0.975) \\
10320-10343(0.012) \\
10352-10374(0.013)\end{array}$ & This work \\
\hline $\begin{array}{r}\text { OS-139002 } \\
(149884)\end{array}$ & 823.5 & c.c. pollen & 303 & -25.2 & $9100 \pm 55$ & $0.3222 \pm 0.0021$ & 10184-10409 (1.000) & This work \\
\hline $\begin{array}{r}\text { OS-138869 } \\
(149885)\end{array}$ & 837.0 & c.c. pollen & 413 & & $9340 \pm 70$ & $0.3126 \pm 0.0027$ & $\begin{array}{l}10297-10357(0.047) \\
10369-10723(0.953)\end{array}$ & This work \\
\hline $\begin{array}{r}\text { OS-139116 } \\
(149886)\end{array}$ & 941.5 & c.c. pollen & 390 & -25.7 & $9020 \pm 50$ & $0.3254 \pm 0.0021$ & $\begin{array}{c}9936-9992(0.070) \\
10008-10030(0.017) \\
10035-10062(0.027) \\
10128-10255(0.886)\end{array}$ & This work \\
\hline
\end{tabular}

(Continued) 
Table 1 (Continued)

\begin{tabular}{|c|c|c|c|c|c|c|c|c|}
\hline $\begin{array}{l}\text { Accession } \\
\text { no. }{ }^{1} \\
\text { (receipt no.) }\end{array}$ & $\begin{array}{l}\text { Core depth }(\mathrm{cm})^{2} / \\
\text { location }\end{array}$ & Material dated ${ }^{3}$ & $\begin{array}{c}\mathrm{C} \\
(\mu \mathrm{g})\end{array}$ & $\begin{array}{c}\delta^{13} \mathrm{C} \\
\% \text { VPDB }\end{array}$ & Age ${ }^{14} \mathrm{C}$ & $\mathrm{F}^{14} \mathrm{C}^{4}$ & $\begin{array}{l}2-\sigma \text { cal BP age range } \\
\text { (probability })^{5}\end{array}$ & Source $^{6}$ \\
\hline \multicolumn{9}{|l|}{$\begin{array}{l}\text { Modern } \\
\text { Pollen }\end{array}$} \\
\hline $\begin{array}{r}\text { OS-149977 } \\
(160235)\end{array}$ & Riddle Lk. TrlHd. & modern pollen & 247 & -30.8 & $80 \pm 15$ & $0.9903 \pm 0.0019$ & $\begin{array}{c}-5(0.003) \\
33-74(0.556) \\
79-81(0.004) \\
98-107(0.023) \\
113-136(0.170) \\
224-254(0.243)\end{array}$ & This work \\
\hline $\begin{array}{r}\text { OS-149978 } \\
(160236)\end{array}$ & Cub Creek Pond & modern pollen & 343 & -31.4 & $50 \pm 20$ & $0.9940 \pm 0.0022$ & $\begin{array}{c}-5(0.024) \\
35-70(0.835) \\
117-131(0.056) \\
231-244(0.081) \\
248-250(0.004)\end{array}$ & This work \\
\hline $\begin{array}{r}\text { OS-149979 } \\
(160237)\end{array}$ & Mud Volcano & modern pollen & 268 & -30.8 & $170 \pm 20$ & $0.9790 \pm 0.0025$ & $\begin{array}{c}-5-31(0.214) \\
138-158(0.111) \\
164-222(0.492) \\
258-285(0.182)\end{array}$ & This work \\
\hline
\end{tabular}

${ }^{1}$ C-\#\# (Chicago), OS-\#\# (National Ocean Sciences Acceleratory Mass Spectrometry).

${ }^{2}$ Depths reported are tops of $1-\mathrm{cm}$ intervals from which samples were collected.

${ }^{3}$ c.c. pollen (chemically concentrated pollen), t. plant remains (terrestrial plant remains).

${ }^{4} \mathrm{FD}-2 \mathrm{~F}^{14} \mathrm{C}$ back-calculated from measured ${ }^{14} \mathrm{C}$ age according to method of Reimer et al. (2004).

${ }^{5}$ Calibrated ranges calculated by CALIB and CALIBomb according to method described in text, parenthetical values relative area under probability distribution.

${ }^{6}$ Source listed for lithological context (FD-2) or calendar age of event. 
Matthews et al. 2015; Wotzlaw et al. 2015), and the entire lake basin was covered by the Yellowstone glacial complex, 25,000-14,000 BP (Licciardi and Pierce 2018). The lake floor today has more than 660 active or recently active hydrothermal vents (Figure 1; Morgan et al. 2007).

Previous studies of sediment cores from Yellowstone Lake provide a postglacial limnogeologic (Tiller 1995) and paleoenvironmental (Theriot et al. 2006) record, making high-resolution age control desirable. In addition, Yellowstone Lake sediments preserve deposits from past hydrothermal explosions (Tiller 1995; Morgan et al. 2009) and volcanic ashes from eruptions in the Cascade Range to the west (Tiller 1995; Theriot et al. 2006). Sediment cores collected in 1992 (FD-2; Figure 1) were dated with radiocarbon ages from terrestrial plant remains (Tiller 1995; Table 1). However, previously unpublished radiocarbon ages collected from humic acid and humin during that study were up to thousands of years older than associated terrestrial plant remains (Table 1) and demonstrate the presence of an old-carbon pool (Figure 2). Radiocarbon ages of bulk sediments and pollen concentrates from Cub Creek Pond $\left(44.505^{\circ} \mathrm{N}, 110.246^{\circ} \mathrm{W}\right.$, elev. 2510 m.a.s.1.) $\sim 4 \mathrm{~km}$ east of Yellowstone Lake also yielded calibrated ages thousands of years older than established by terrestrial plant remains or tephrochronology (Whitlock 1993; Lu et al. 2017).

Our objective in this study was to answer the following questions: (1) How do radiocarbon ages from different terrestrial materials in Yellowstone Lake sediments compare? (2) What is the carbon source for pollen concentrates from Yellowstone Lake sediments that might lead to erroneously old ages? To answer these questions, we explore a suite of AMS radiocarbon ages from several sediment cores from the northern basin of Yellowstone Lake and compare them with independent age controls and the radiocarbon ages of living plant material.

\section{METHODS}

Sediment cores from the northwest area (core $2 \mathrm{C}, 44.53927^{\circ} \mathrm{N}, 110.38922^{\circ} \mathrm{W}$, water depth 61 $\mathrm{m}$ ) and southeast area (core $5 \mathrm{~A}, 44.50782^{\circ} \mathrm{N}, 110.32685^{\circ} \mathrm{W}$, water depth $102 \mathrm{~m}$ ) of the northern basin of Yellowstone Lake were collected in September 2016 with a Kullenberg sampler (Figure 1; Kelts et al. 1986). Additional cores were retrieved near the 2C (13A) and 5A (9A) sites with a gravity sampler in July 2017 to recover the most recent sediments. Cores were transported to the National Lacustrine Core Facility (LacCore, University of Minnesota) where they were longitudinally split, photographed, and stored under refrigeration except when sampled or during core-scanning analyses. Kullenberg and gravity cores were correlated on the basis of core imagery and charcoal stratigraphy, producing two complete records for analysis, core $2 \mathrm{C} / 13 \mathrm{~A}$ and core $5 \mathrm{~A} / 9 \mathrm{~A}$.

Initial stratigraphic AMS age determinations for core 2C/13A were derived from terrestrial plant remains (needles, charcoal, or unidentified wood fragments) and pollen concentrates. Bulk-sediment ages were avoided based on erroneously old ages previously obtained from humin in the FD-2 core (Figure 2; Table 1). Plant remains were collected wherever present, identifiably terrestrial, and large enough for analysis. Five terrestrial plant remains were identified, extracted from core sediments, washed in distilled water, and placed under a dissection microscope where extraneous sediment was removed with a teasing needle. Initial pollen samples were collected from $1-\mathrm{cm}$ intervals immediately above and below a thick hydrothermal explosion deposit and wherever substantial stratigraphic gaps occurred in the spacing of terrestrial plant remains. Pollen was concentrated by traditional pollen 

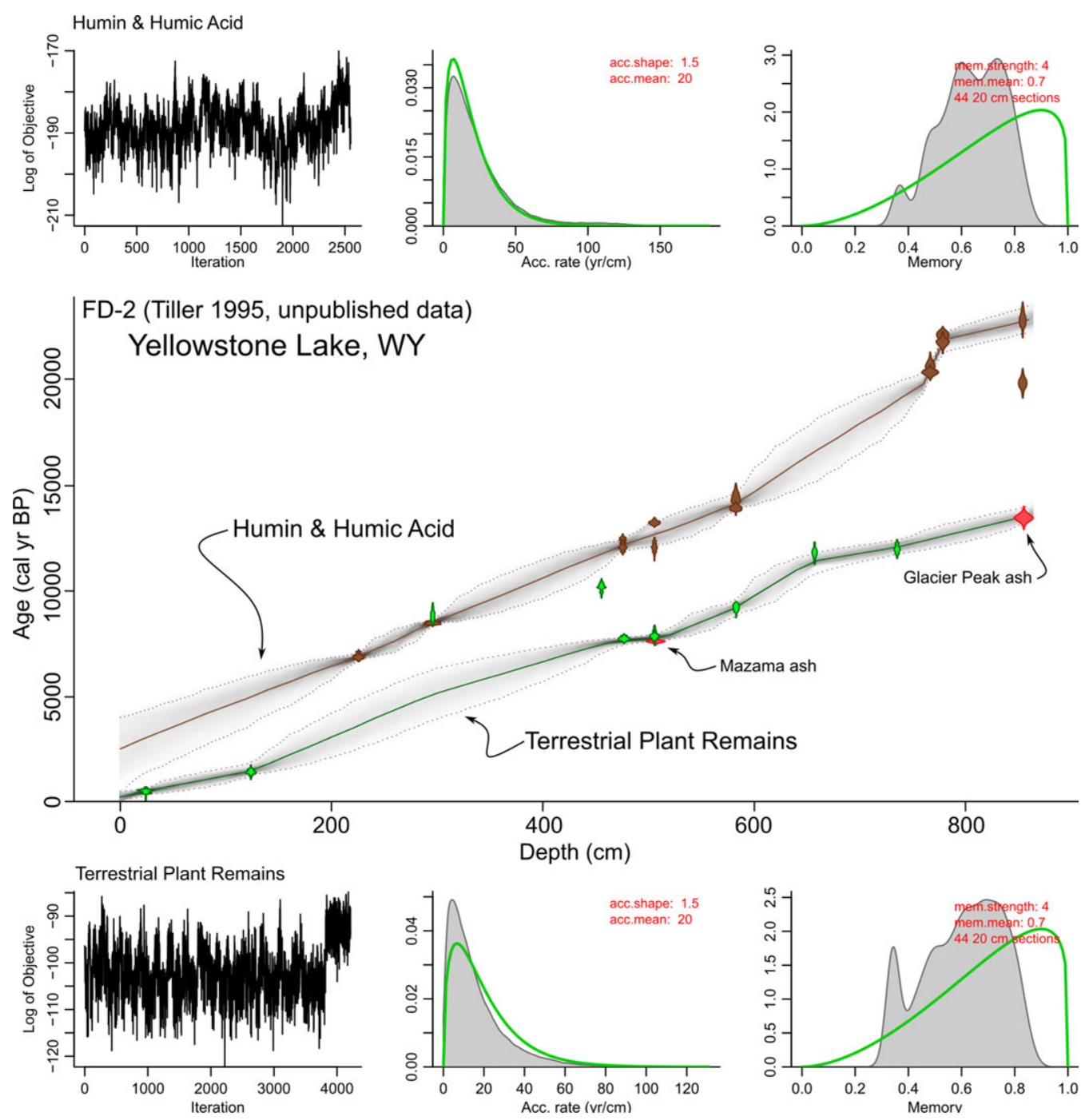

Figure 2 Bacon age-depth models for Yellowstone Lake (FD-2 from Tiller 1995) derived from bulk sediment components, humin and humic acid (brown), terrestrial plant remains (green; Tiller 1995), and ashes (red). Younger ash is Mazama (7682-7584 cal BP, 2- $\sigma$ range, Egan et al. 2015) and the older is Glacier Peak B or G (13,410-13,710 cal BP, 2- $\sigma$ range, Kuehn et al. 2009) as determined by petrographic analysis of Tiller (1995).

maceration procedures (Bennett and Willis 2001). Sediments were disaggregated and humic compounds removed with $0.9 \mathrm{~N} \mathrm{KOH}$ treatment (near-boiling hot bath, $2.5 \mathrm{~min}$ ) and rinsed with distilled water, centrifuged, and decanted until the supernatant was clear. Large particles were wet-sieved with distilled water through a $180 \mu \mathrm{m}$ mesh. Carbonates were removed with $2.7 \mathrm{~N} \mathrm{HCl}$ treatment (near-boiling hot bath, until no effervescence was observed) and silicates were removed with $28.9 \mathrm{~N} \mathrm{HF}$ (near-boiling hot bath, $60 \mathrm{~min}$ ). Acetolysis was foregone in favor of oxidation in $15.9 \mathrm{~N} \mathrm{HNO}_{3}$ (near-boiling hotbath, $3 \mathrm{~min}$ ) to remove cellulose while avoiding carbon-bearing acetate solutions. Samples were rinsed with distilled water, centrifuged, and decanted until the slurry was neutral. These samples are hereafter referred to as chemically concentrated pollen. 
Paired bulk-sediment and picked-pollen concentrate samples also were collected from stratigraphic locations (in 1-cm intervals) where ages were known independently. Bulksediment and picked-pollen samples were collected at the sediment-water interface (core top) in the gravity cores (13A, 9A) where the true age was approximately the year of coring ( -67 cal BP). Further bulk-sediment and picked-pollen samples were collected from Kullenberg cores (2C, 5A) immediately above what is likely the Mazama ash (Tiller 1995; Theriot et al. 2006). These tephra (2C,5A), along with a new analysis of the younger Tiller (1995) tephra from core FD-2, were sampled and analyzed at the New Mexico Bureau of Geology and Mineral Resources on a Cameca SX-100 electron microprobe to confirm the geochemical correlation between the cores, and to the Mazama ash. Picked-pollen samples were obtained utilizing the maceration procedures described above and a modified pipetting procedure from Mensing and Southon (1999). Sieving with 90 and $38 \mu \mathrm{m}$ mesh screens targeted Pinus pollen and further concentration was managed by picking with a micropipette under a stereomicroscope $(63 \times$ magnification $)$. Pipette suction was gently produced by a syringe in place of the mouth. Identification under the stereomicroscope was generally only possible at the level of Pinaceae, so picked-pollen samples likely contained some mixture of Pinus, Abies, and Picea. It was not practical to count grains during the picking procedure, but resultant mass of $\mathrm{C}, 22-58 \mu \mathrm{g}$, was comparable to the yields of Mensing and Southon (1999).

Finally, to confirm that the carbon isotope composition of the pollen, like wood, reflects the atmospheric radiocarbon activity, modern pollen was collected from Pinus contorta trees in the Yellowstone Lake vicinity (Figure 1). Pollen (male) cones were collected from trees at three locations near Yellowstone Lake in June 2019: (1) upwind of Yellowstone Lake near the Riddle Lake Trailhead, (2) downwind of Yellowstone Lake near Cub Creek Pond, and (3) near Mud Volcano, where uptake of radiometrically old carbon has been previously documented in Pinus contorta tree rings $\left(\mathrm{F}^{14} \mathrm{C}\right.$ up to 0.35 lower than NHZ1 post-bomb curve; Evans et al. 2010). Due to a cold, wet spring, pollen production was late, and samples collected in June 2019 were probably from the 2018 crop. Pollen was rinsed off of cones and sieved through 90 and $38 \mu \mathrm{m}$ mesh screens to remove extraneous material and treated with Schulze solution $\left(1: 10 \mathrm{wt}(\mathrm{g}) / \mathrm{vol}(\mathrm{mL})\right.$ mixture $\mathrm{KClO}_{3}$ in $15.9 \mathrm{~N} \mathrm{HNO}_{3}$, nearboiling hot bath, $3 \mathrm{~min}$ ) to remove extraneous organics (Doher 1980). Samples were rinsed in distilled water, centrifuged, and decanted until the slurry was neutral.

AMS age determinations were made by the National Ocean Sciences AMS (NOSAMS) facility at the Woods Hole Oceanographic Institute. Traditional pretreatment was conducted only for terrestrial plant remains using a modified acid-base-acid method to remove non-structural carbon (de Vries and Barendsen 1954) and bulk sediments were treated with $2.7 \mathrm{~N} \mathrm{HCl}$ (McNichol et al. 1994). Pollen-concentrate samples were combusted without any further treatment at NOSAMS since previous concentration procedures made further pretreatment redundant. Pollen-concentrate samples were generally very small, $<0.1 \mathrm{mg}$ total sample mass. To preserve as much of the sample as possible, concentrates were shipped in dilute $\mathrm{HCl}$ in distilled water with subsequent filtering onto pre-baked quartz fiber filters, rinsed to neutral, dried, and combusted at $850^{\circ} \mathrm{C}$ in sealed quartz tubes. Carbon yields from pollen concentrates ranged from 22 to $569 \mu \mathrm{g}$ C. Radiocarbon results were blank corrected for the possible addition of contaminants during sample processing and AMS measurement. For samples that yielded $<100 \mu \mathrm{g}$ carbon, a mass-balance correction was made according to Roberts et al. (2019). For larger sample masses, the mass-dependent correction is relatively small, and an average large mass blank value from acetanilide samples (used as a home 
blank due to the unavailability of ${ }^{14} \mathrm{C}$-free pollen material) measured concurrently with the unknown sample was used to correct the result. When samples were large enough, a split of $\mathrm{CO}_{2}$ was sent to a stable mass spectrometer for $\delta^{13} \mathrm{C}$ analysis to aid in the verification of results and identification of anachronous carbon sources including aquatic plants and carbonate rock.

Radiocarbon ages were calibrated with CALIB (version 7.1, Stuiver et al. 2019) utilizing the IntCal13 calibration curve (Reimer et al. 2013). Calibrated ages were further refined and interpreted in the context of stratigraphic depth through development of two age-depth models using Bacon software (rbacon version 2.3.9.1, Blaauw and Christen 2011) based on chemically concentrated pollen and terrestrial plant remains. A priori assignment of mean sediment accumulation rate was set to $10 \mathrm{yr} \mathrm{cm}^{-1}$, as suggested by Bacon and closely matching our data, but is somewhat faster than Holocene sediment accumulation rates estimated for other, deeper parts of Yellowstone Lake $\left(\sim 15 \mathrm{yr} \mathrm{cm}^{-1}\right.$, Tiller $1995 ; 17-10 \mathrm{yr}$ $\mathrm{cm}^{-1}$, Johnson et al. 2003). Thickness for spline calculation was set to $20 \mathrm{~cm}$, above which the model diverged greatly from provided age controls. A priori parameters were held constant for age-depth models based on chemically concentrated pollen and terrestrial plant remains, and independent age controls were included in both models. Instantaneous deposits resulting from volcanic ashfall or hydrothermal explosions were relatively thin in this core $(<5 \mathrm{~cm})$ and not excised from the total core depth.

\section{RESULTS}

\section{Radiocarbon Results}

Calibrated radiocarbon ages for core $2 \mathrm{C} / 13 \mathrm{~A}$ are presented in Table 1, along with nonradiocarbon ages: the core top, a prominent charcoal peak from a large fire that occurred ca. $1700 \mathrm{CE}$ (based on tree-ring analysis in the watershed; error assigned to \pm 10 years on the basis of two prominent decades of stand establishment; Romme and Despain 1989; Higuera et al. 2010), and the geochemically fingerprinted Mazama ash (Table 2). All three lake-core tephra are geochemically identical to the Mazama ash (Jensen and Beaudoin 2016) allowing for time to be correlated across Yellowstone lake. The age of the climactic Mt. Mazama eruption is well established in ice-core records (7777-7477 cal BP, 2- $\sigma$ range; Zdanowicz et al. 1999) and by thorough radiocarbon dating efforts (7682-7584 cal BP, 2- $\sigma$ range; Egan et al. 2015). One radiocarbon result from unidentified plant remains (OS-142084) was excluded from the terrestrial plant age-depth model, given its erroneously old age and a $\delta^{13} \mathrm{C}$ value of $-10.9 \%$, both of which are consistent with an aquatic plant fragment.

The age-depth models from chemically concentrated pollen and terrestrial plant remains diverge, except at the top of the core where closely spaced calendar ages enforce unity (Figure 3). Modelled median calibrated ages from pollen concentrates ranged from 1700 to 4300 years older than the modelled median calibrated ages from terrestrial plants. Ages from chemically concentrated pollen were internally consistent, with no ages falling outside the 2- $\sigma$ range of the age-depth model, but they too did not agree with the age of the Mazama ash. The Mazama ash age was rejected by Bacon as an outlier in the chemically concentrated pollen model. Terrestrial plant remain ages were also internally consistent, with only one age outside the 2- $\sigma$ range, and the age model aligned well with the age of the Mazama ash (Figure 3). 
Table 2 Summary of normalized ${ }^{1}$ geochemical data from Yellowstone Lake Mazama ash samples compared with UA2832 of Jensen and Beaudoin (2016).

\begin{tabular}{|c|c|c|c|c|c|c|c|c|c|c|c|c|c|c|c|c|}
\hline Sample & $\mathrm{n}^{2}$ & $\mathrm{P}_{2} \mathrm{O}_{5}$ & $\mathrm{SiO}_{2}$ & $\mathrm{SO}_{2}$ & $\mathrm{TiO}_{2}$ & $\mathrm{Al}_{2} \mathrm{O}_{3}$ & $\mathrm{MgO}$ & $\mathrm{CaO}$ & $\mathrm{MnO}$ & $\mathrm{FeO}^{3}$ & $\mathrm{Na}_{2} \mathrm{O}$ & $\mathrm{K}_{2} \mathrm{O}$ & $\mathrm{F}$ & $\mathrm{Cl}$ & Total & Analytical total \\
\hline$\overline{2 C}$ & 9 & 0.07 & 72.77 & 0.01 & 0.45 & 14.22 & 0.43 & 1.64 & 0.05 & 2.00 & 5.25 & 2.84 & 0.10 & 0.17 & 100 & 99.09 \\
\hline . & & 0.03 & 0.08 & 0.01 & 0.03 & 0.06 & 0.03 & 0.04 & 0.02 & 0.04 & 0.08 & 0.04 & 0.01 & 0.01 & & 1.35 \\
\hline 5A & 12 & 0.06 & 72.78 & 0.02 & 0.42 & 14.20 & 0.43 & 1.64 & 0.06 & 2.03 & 5.28 & 2.79 & 0.11 & 0.19 & 100 & 97.33 \\
\hline$\sigma$ & & 0.03 & 0.15 & 0.01 & 0.04 & 0.10 & 0.03 & 0.06 & 0.02 & 0.06 & 0.18 & 0.07 & 0.01 & 0.04 & & 1.32 \\
\hline FD-2 & 9 & 0.08 & 72.87 & 0.01 & 0.41 & 14.25 & 0.42 & 1.62 & 0.05 & 1.99 & 5.24 & 2.77 & 0.11 & 0.19 & & 97.56 \\
\hline$\sigma$ & & 0.03 & 0.21 & 0.01 & 0.04 & 0.08 & 0.03 & 0.05 & 0.01 & 0.06 & 0.12 & 0.05 & 0.03 & 0.07 & & 2.63 \\
\hline UA2832 & 21 & & 72.84 & & 0.44 & 14.73 & 0.47 & 1.64 & 0.05 & 2.01 & 4.88 & 2.77 & & 0.18 & 100 & 96.97 \\
\hline$\sigma$ & & & 0.93 & & 0.07 & 0.34 & 0.11 & 0.25 & 0.02 & 0.28 & 0.16 & 0.16 & & 0.03 & & \\
\hline
\end{tabular}

${ }^{1}$ Data has been normalized to $100 \%$ and the analytical total are presented for each sample. Oxidized reported as wt. \%. Glass shards were analyzed on a Cameca SX100 with four WDS spectrometers an accelerating voltage of $15 \mathrm{kV}$ and a probe current of $10 \mathrm{nA}$ and a beam diameter of 20 microns were used. Count times $=20 \mathrm{~s}$ except $\mathrm{S}=30 \mathrm{~s}, \mathrm{Cl}=40$ and $\mathrm{F}=60$. Analytical precision from microprobe analyses is calculated by the standard deviation of replicate analyses of secondary standard VG568, are as follows (in wt. $\%$ ): $\mathrm{P}_{2} \mathrm{O}_{5}$ $\pm 0.01, \mathrm{SiO}_{2} \pm 0.23, \mathrm{SO}_{2} \pm 0.01, \mathrm{TiO}_{2} \pm 0.02, \mathrm{Al}_{2} \mathrm{O}_{3} \pm 0.08, \mathrm{MgO} \pm 0.01, \mathrm{CaO} \pm 0.01, \mathrm{MnO} \pm 0.02, \mathrm{FeO} \pm 0.06, \mathrm{Na} 2 \mathrm{O} \pm 0.23, \mathrm{~K} 2 \mathrm{O} \pm 0.06, \mathrm{~F} \pm 0.08, \mathrm{Cl} \pm 0.01$.

2 Number of analyses.

${ }^{3} \mathrm{FeO}$ total. 

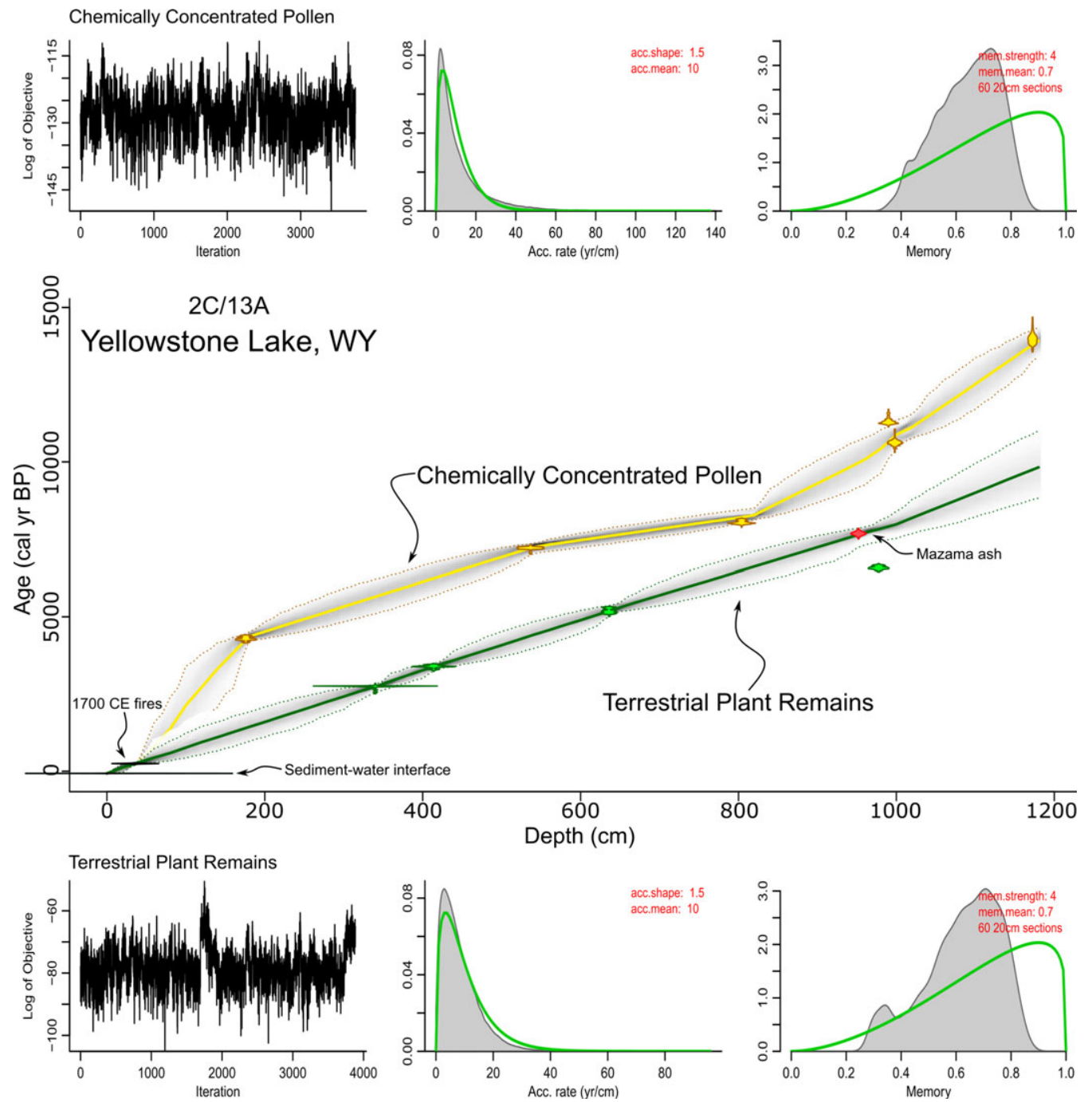

Figure 3 Bacon age-depth models for Yellowstone Lake (core 2C) derived from chemically concentrated pollen (yellow), terrestrial plant remains (green), the Mazama ash (red), and calendar ages of the coring date and a fire at $1700 \mathrm{CE}$.

Paired bulk-sediment and picked-pollen sample ages were calibrated utilizing Intcal13 (Reimer et al. 2013) and plotted with CALIB (version 7.1, Stuiver et al. 2019, Figure 4). Bulk-sediment ages were 4600 and 6000 cal years too old $\left(\mathrm{F}^{14} \mathrm{C} 0.6017 \pm 0.0019\right.$ and $\left.0.5203 \pm 0.0017\right)$ at the sediment-water interface and 5300 and 5400 cal years too old directly above Mazama ash $\left(\mathrm{F}^{14} \mathrm{C}\right.$ $0.2524 \pm 0.0016$ and $0.2497 \pm 0.0016$ ). Picked-pollen samples offered an improvement, with ages that were 1900 and 2400 cal years too old at the sediment-water interface $\left(\mathrm{F}^{14} \mathrm{C}\right.$ $0.7885 \pm 0.0109$ and $0.7505 \pm 0.0164$ ). Directly above the Mazama ash, the picked pollen age from 2C/13A (OS-142018) was 4300 cal years too old directly above the Mazama ash $\left(\mathrm{F}^{14} \mathrm{C} 0.2793 \pm 0.0059\right)$, while the age from 5A/9A (OS-142221) was 1300 cal years too young $\left(\mathrm{F}^{14} \mathrm{C} 0.5021 \pm 0.0083\right)$. The lower precision and resultant posterior distributions of 


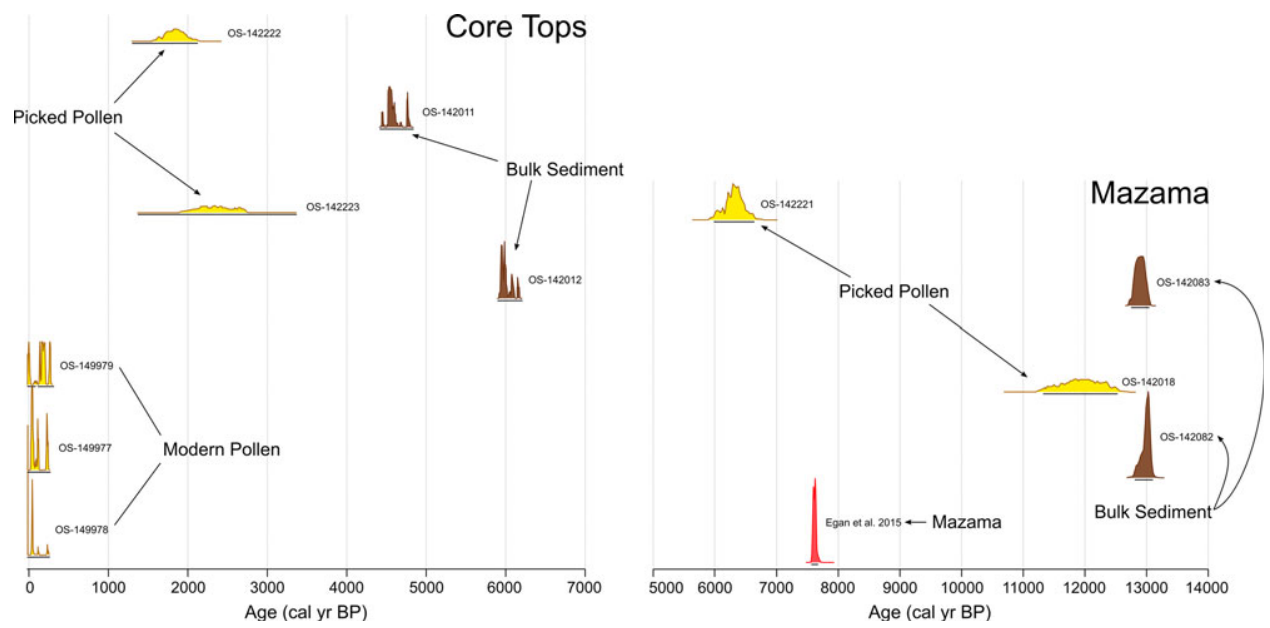

Figure 4 Probability density plots of dates from multiple materials at depths with known ages. Core top ages should be the approximate year of coring or pollen cone collection, -67 and -68 cal BP, respectively. The Mazama samples were collected immediately above the Mazama ash, which was deposited at 7682-7584 cal BP (2- $\sigma$ range, Egan et al. 2015). All ages from Yellowstone Lake cores, except OS-142221, are erroneously old by thousands of years. Picked-pollen ages have wide age distributions owing to small sample sizes.

picked-pollen ages were much wider than bulk-sediment ages, and understandably so, due to the larger uncertainties involved with small mass sample analysis.

Radiocarbon results from modern pollen from the Riddle Lake Trailhead, Cub Creek Pond, and Mud Volcano demonstrate virtually modern $\mathrm{F}^{14} \mathrm{C}$ values of $0.9903 \pm 0.0019,0.9940 \pm$ 0.0022 , and $0.9790 \pm 0.0025$, respectively (Figure 4). These $\mathrm{F}^{14} \mathrm{C}$ values were calibrated utilizing CALIBomb (Reimer and Reimer 2004, Figure 4) with the NHZ1 post-bomb calibration (Hua et al. 2013) and IntCal13 pre-bomb calibration (Reimer et al. 2013).

\section{$\delta^{13} \mathrm{C}$ Results}

Where samples were large enough, a split of $\mathrm{CO}_{2}$ from combusted samples was analyzed for $\delta^{13} \mathrm{C}$ as well as for radiocarbon, and the results were compared with existing $\delta^{13} \mathrm{C}$ values obtained in earlier studies (Figure 5). Bulk sediments had less depleted $\delta^{13} \mathrm{C}$ values than terrestrial plant remains, indicative of a non-terrestrial plant carbon source in the sediment. With the exception of one outlier, $\delta^{13} \mathrm{C}$ values from terrestrial plant remains fell within the accepted range for terrestrial $C_{3}$ plants (Smith and Epstein 1971). Chemically concentrated pollen $\delta^{13} \mathrm{C}$ values were widely variable, however, with one outlier nearly at $0 \%$ VPDB. All $\delta^{13} \mathrm{C}$ values from sediment core samples were less depleted than those from modern pollen cones, which were $-31.0 \%$ VPDB on average. $\delta^{13} \mathrm{C}$ values did also vary somewhat from site to site, but with no apparent spatial pattern (Figure 5). Cub Creek Pond samples had the least depleted values (average $-20.8 \%$ VPDB), with slightly more depleted values from 5A/9A (average -20.8\% VPDB), Hedrick Pond (located $60 \mathrm{~km}$ south of Yellowstone Lake, $43.754^{\circ} \mathrm{N}, 110.590^{\circ} \mathrm{W}$, elev. 2055 m.a.s.1.; average $-25.8 \%$ VPDB), and $2 \mathrm{C} / 13 \mathrm{~A}$ (average $-27.2 \%$ VPDB). 

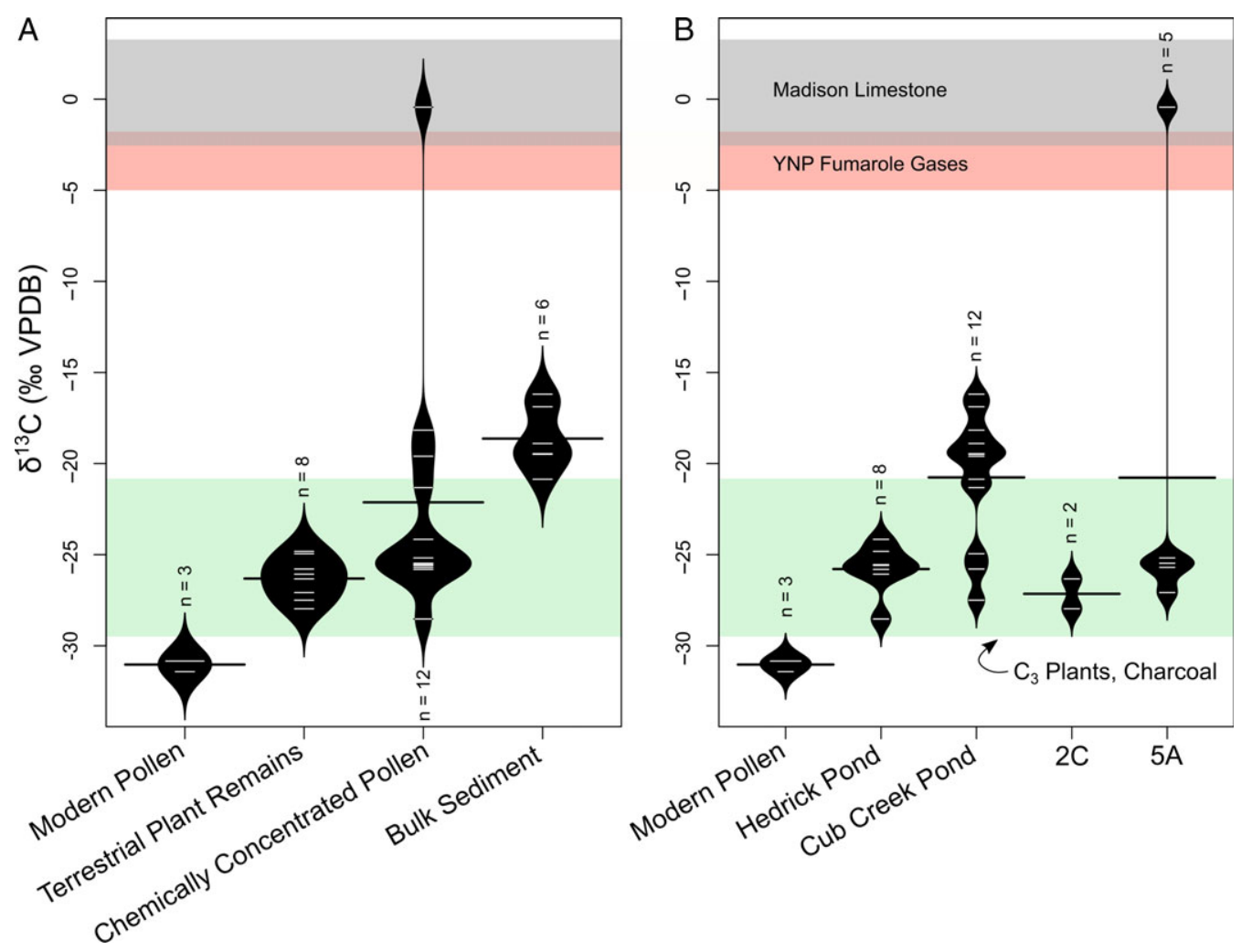

Figure $5 \quad \delta^{13} \mathrm{C}$ values of radiocarbon materials are plotted using beanplot (Kampstra 2008) by material (A) and by site (B). $C_{3}$ plant and charcoal ranges are given by Smith and Epstein (1971). $\mathrm{n}$ is the number of samples included in each distribution. Yellowstone National Park (YNP) fumarole gas range taken from Craig (1963) and Werner and Brantley (2003) with Mississippian Madison Limestone range taken from Friedman (1970). Data from Hedrick Pond and Cub Creek Pond from Lu et al. (2017). Chemically concentrated pollen has a wide range of $\delta^{13} \mathrm{C}$ values and the majority of least negative values come from areas near hydrothermal areas (Cub Creek Pond and Yellowstone Lake).

\section{DISCUSSION}

\section{Comparison of Radiocarbon Ages from Yellowstone Lake}

In Yellowstone Lake, ages from chemically concentrated pollen were systematically and erroneously old, compared with ages established from terrestrial plant remains, tephrochronology, or the date of the sediment-surface interface (Figure 4). Chemically concentrated pollen ages from core $2 \mathrm{C} / 13 \mathrm{~A}$ were systematically older than terrestrial plant remains ages by up to 4300 cal years and disagree with the established age of the Mazama ash (7682-7584 cal BP, 2- $\sigma$ range; Egan et al. 2015) by 2300 cal years. Ages from strata of known age corroborate this finding, as picked Pinaceae pollen ages offered an improvement on bulk-sediment ages, but resultant ages remained too old by 1900 to 4300 cal years. These results are consistent with previous efforts at dating bulk sediments from Yellowstone Lake (Figure 2; Table 1) and bulk sediment and pollen concentrates from Cub Creek Pond (Whitlock 1993; Lu et al. 2017). Ages from living Pinus contorta pollen are virtually modern by comparison (in equilibrium with atmospheric $\mathrm{CO}_{2}$ ). 


\section{Carbon Source of Yellowstone Terrestrial Pollen}

Previous studies (referenced below) have reported erroneously old pollen ages in sediment cores and attributed the introduction of old carbon to (1) laboratory processes; (2) incomplete removal of non-pollen materials during concentration procedures; (3) reworked pollen; and/ or (4) enrichment of old $\mathrm{CO}_{2}$ in source material. The likelihood of these explanations is explored below.

First, accidental contamination is a major concern in laboratories that prepare samples for AMS radiocarbon dating. Most laboratories contain potential sources of old carbon including sodium bicarbonate $\left(\mathrm{NaHCO}_{3}\right)$ and petrochemicals. $\mathrm{NaHCO}_{3}$ is found in most pollen preparation fume hoods to neutralize surfaces exposed to caustic acids; however, it was not actively used in the fume hood during these analyses and would have been removed through subsequent acidification. Petrochemicals were not used as reagents in the pollen preparation laboratory. Definitively, additional studies that used the same pollen preparation environment and procedure have not reported difficulty with old ages from chemically concentrated pollen (Krause and Whitlock 2013; Krause et al. 2015; Nanavati et al. 2019), making systematic laboratory contamination from old carbon or fractionation unlikely sources of error.

Second, old-carbon contamination from incomplete removal of non-pollen materials is commonly cited as an issue in procedures for concentrating pollen (Regnéll 1992; Richardson and Hall 1994), and sedimentological sources of old carbon exist in the vicinity. The Mississippian Madison Limestone, which is exposed in northern Yellowstone National Park outside the caldera, produces near-zero $\delta^{13} \mathrm{C}$ values (Figure 5; Friedman 1970), but does not crop out near or upstream of Yellowstone Lake nor does any other significant carbonate formation (U.S. Geological Survey 1972). Moreover, lake waters are relatively depleted in dissolved carbonate $\left(<0.8 \mathrm{mM} \Sigma \mathrm{CO}_{2}\right.$, Balistrieri et al. 2007). Lake sediments themselves are not reported to contain carbonate mud (e.g. Tiller 1995), contain $<1 \mathrm{wt} \% \mathrm{CaO}$ (Shanks et al. 2007), and do not effervesce when submerged in hot $2.7 \mathrm{~N} \mathrm{HCl}$. Also, acidification treatments would remove most carbonates. Although our samples had no bituminous odor, we acknowledge that thermogenic hydrocarbons are found in several subaerial thermal areas of Yellowstone National Park (Love and Good 1970; Clifton et al. 1990) and probably occur in hydrothermally altered sediments of Yellowstone Lake (Shanks et al. 2007). Core 2C/13A is not located near known hydrothermal vents (Figure 1); however, hydrocarbon contamination remains possible in core 5A/9A. Importantly, pollen ages remained erroneously old (with the exception of OS-142221) regardless of increasingly thorough concentration procedures through Schulze treatment and manual picking. Although chemically concentrated pollen ages were unilaterally more accurate than bulk-sediment ages, suggesting concentration procedures removed some old carbon, the calibrated ages of chemically concentrated and picked pollen were similar. The manually picked pollen probably produces the purest pollen sample currently possible, so erroneous ages in these samples probably reflect the age of the pollen grains with minimal sediment contaminants. Examination of picked pollen concentrates under a transmitted light microscope at $400 \times$ magnification confirmed the general absence of sediment contaminants. Remaining contaminant particles would have been too small to be detected under the stereomicroscope and insoluble in our chemical treatments. 
Third, reworked pollen is suggested as a major source of old-carbon contamination in lacustrine settings where extensive old lacustrine deposits occur at the surface (Mensing and Southon 1999; Zimmerman et al. 2019) or redeposition occurs from glacial melt (Neulieb et al. 2013; Zhang et al. 2017). There is no evidence of a Holocene glacial meltwater source in the Yellowstone Lake watershed. Given the size of the Yellowstone depositional basin and the preponderance of pollen types that are produced in great abundance and distributed widely (e.g. Pinus, Artemisia), a hypothetical ancient pollen source would need to be very large. Most unconsolidated surficial sediments were removed from the basin during repeated glacial episodes (Licciardi and Pierce 2018). Remaining exposures of ancient lake sediments occur upstream (Baker 1986) and downstream (Love et al. 2007) but are patchy and very small. Ancient shoreline facies also occur north of Yellowstone Lake (Pierce et al. 2007), but are situated upstream of the lake, probably too small to be the source area, and the coarse gravels and shallow-water depositional environments are not a good pollen preservation environment. Furthermore, pollen grains subjected to reworking should be observably broken and degraded under the light microscope (Tweddle and Edwards 2010; Howarth et al. 2013), but pollen preservation was generally excellent in Yellowstone Lake, as we observed that $<1 \%$ of the pollen grains were unidentifiable and $>50 \%$ of Pinus pollen had intact, distal membranes that allowed assignment to the subgeneric level under $400 \times$ magnification. Finally, dated terrestrial plant remains were clearly not out-of-sequence, and Holocene pollen spectra, dominated throughout core $2 \mathrm{C}$ by Pinus $(>55 \%,<79 \%)$, are consistent with data from nearby sites within Pinus contorta forest (e.g., Baker 1976; Whitlock 1993; Whitlock et al. 1995; Theriot et al. 2006), further evidence against a significant component of reworked pollen.

Fourth, $\mathrm{CO}_{2}$ vented from the Yellowstone Caldera is a somewhat unique source of old carbon in this region. Yellowstone Lake vents comprise a very active thermal area and account for an estimated $10 \%$ of the thermal water flux in Yellowstone National Park (Balistrieri et al. 2007); in addition, a small, subaerial thermal area exists upslope of Cub Creek Pond (Vaughan et al. 2014). These areas potentially constitute a large source of old-carbon flux, although no estimates exist for the hydrothermal carbon budget of Yellowstone Lake, and the Cub Creek Thermal Area is of unknown chemistry and considered potentially inactive (Vaughan et al. 2014). $\delta^{13} \mathrm{C}$ values of pollen from Yellowstone Lake and nearby Cub Creek Pond (Lu et al. 2017) suggest an admixture of sources with less depleted $\delta^{13} \mathrm{C}$ values than are typical for $\mathrm{C}_{3}$ plants (Figure 5). Locally, fumarole gases produce the opposite end member of this admixture (Craig 1963; Werner and Brantley 2003). Large volumes of $\mathrm{CO}_{2}$ are degassed from magmatic and pre-Tertiary basement sources at present, with daily, caldera-wide degassing estimated at $45( \pm 16) \mathrm{kt}$ primarily from acid-sulfate hydrothermal features (Werner and Brantley 2003). Uptake of volcanically derived old $\mathrm{CO}_{2}$ has been inferred elsewhere. For example, lake-sediment cores from volcanic lakes in Anatolia with bulksediment ages document reservoir effects of up to 14,000 years (Roberts et al., 2001; Jones 2004). In other settings, uptake of old $\mathrm{CO}_{2}$ through photosynthesis has been inferred in living plant tissue at sites near hydrothermal vents (Pasquier-Cardin et al. 1999; Cook et al. 2001; Evans et al. 2010; Lewicki and Hilley 2014) and industrial areas (Baydoun et al., 2015), but generally do not occur more than $1 \mathrm{~km}$ away from the old-carbon source (Pasquier-Cardin et al. 1999; Evans et al. 2010; Baydoun et al. 2015). This observation is consistent with dates from modern pollen near Yellowstone Lake (Figure 4), which suggest minimal uptake of volcanic $\mathrm{CO}_{2}$ through photosynthesis. 
Potential sources for old-carbon contamination are narrowed by the fact that cone pollen collected in 2018 has the same $\mathrm{F}^{14} \mathrm{C}$ as atmosphere and picked pollen from core tops is erroneously old. This limits the potential place of contamination to the water column or surficial lake sediments. However, it is unclear how hydrothermal carbon could be incorporated into pollen grains in either context, given that sporopollenins, which compose the chemically resistant coating of the pollen exine (outer wall), are "...p probably the most resistant organic materials of direct biological origin found in nature..." (Brooks and Shaw 1978). This hypothesis is also unsatisfactory given that old-carbon contamination of organic compounds by hydrothermal carbon apparently did not impact other terrestrial plant remains in the sediments.

\section{CONCLUSIONS}

Pollen concentrate ages are systematically older than terrestrial plant remains ages in Yellowstone Lake by 1700 to 4300 cal years and we can offer no clear explanation for this puzzlement. The most likely sources of old carbon are (1) $\mathrm{CO}_{2}$ degassing from magmatic and pre-Tertiary basement sources, which may be incorporated into pollen grains in the water column or in surficial sediments; or (2) reworked pollen from older sediments. Neither explanation is fully adequate. In our consideration, further study of the radiocarbon signature of modern pollen from its production to its release, transport, deposition, and final burial in lake sediments is required to locate the source of old-carbon contamination. Such an investigation should include radiocarbon dating of modern pollen from the cone, pollen intercepted from the local atmosphere, pollen in the water column and carbon isotope analysis of the DOC in lake water. Experiments may be also be employed in the laboratory to explore the possibility of incorporation of old carbon from artificially sourced $\mathrm{CO}_{2}$ into pollen grains in an aqueous mixture. Future experiments may also examine the impact of individual steps in pollen concentration procedures for carbon contamination, obtain ${ }^{14} \mathrm{C}$-free pollen concentrates as a more representative blank material, and utilize SEM microscopy to detect remaining contaminants associated with pollen grains.

With the current problem of old radiocarbon ages from pollen concentrates and the lack of other suitable materials for radiocarbon dating, we continue to be limited in our ability to produce quality age control for paleoenvironmental and geological reconstructions from Yellowstone Lake, Cub Creek Pond, and potentially other sites in the Yellowstone Caldera (e.g. Lewis Lake, glacial Yellowstone Lake). Current results underscore the necessity of careful consideration of carbon source-even in terrestrial plant remains and pollen concentrates-where reworked sediments or old-carbon degassing are possible.

\section{ACKOWLEDGMENTS}

This research was supported by NSF Grant No. 1515353 to C. Whitlock and sampling in Yellowstone National Park was conducted under permits YELL-SCI-0009 and YELL-SCI5054. Coring efforts at Yellowstone Lake were aided by M. Baker, S.R. Brown, D. Conley, S.C. Fritz, C. Linder, L.A. Morgan, R. O’Grady, W.C. Shanks III, M.D. Shapley, R.A. Sohn, and three anonymous Yellowstone National Park rangers. This project was greatly improved through conversations with J. Southon and S.R.H. Zimmerman and thoughtful reviews of the manuscript came from D. McWethy, L.A. Morgan, D.A. Orme, and W.C. Shanks III. 


\section{REFERENCES}

Baker RG. 1976. Late Quaternary vegetation history of the Yellowstone Lake Basin, Wyoming. U.S. Geological Survey Professional Paper 729-E.

Baker RG. 1986. Sangamonian(?) and Wisconsinan paleoenvironments in Yellowstone National Park. GSA Bulletin 97(6):717-736. doi: 10.1130/ 0016-7606(1986)972.0.CO;2.

Balistrieri LS, Shanks WC III, Cuhel RL, Aguilar C, Val Klump J. 2007. The influence of sublacustrine hydrothermal vent fluids on the geochemistry of Yellowstone Lake. In: Morgan LA, editor. Integrated geoscience studies in the greater Yellowstone area-volcanic, tectonic, and hydrothermal processes in the Yellowstone geoecosystem. U.S. Geological Survey Professional Paper 1717.

Baydoun R, El Samad O, Nsouli B, Younes G. 2015. Measurement of ${ }^{14} \mathrm{C}$ Content in Leaves near a Cement Factory in Mount Lebanon. Radiocarbon 57(1):153-159. doi: 10.2458/ azu_rc.57.18108.

Bennett KD, Willis KJ. 2001. Pollen. In: Smol JP, Birks HJB, Last WM, editors. Tracking environmental change using lake sediments. Volume 3: terrestrial, algal, and siliceous indicators. Dordrect, NL: Kluwer Academic Publishers.

Blaauw M, Christen JA. 2011. Flexible paleoclimate age-depth models using an autoregressive gamma process. Bayesian Anal. 6(3):457-474. doi: 10. 1214/11-BA618.

Brooks J, Shaw G. 1978. Sporopollenin: a review of its chemistry, palaeochemistry and geochemistry. Grana 17(2):91-97. doi: 10.1080/ 00173137809428858.

Brown TA, Nelson DE, Mathewes RW, Vogel JS, Southon JR. 1989. Radiocarbon dating of pollen by accelerator mass spectrometry. Quaternary Research 32:205-212. doi: 10.1016/ 0033-5894(89)90076-8.

Christiansen RL. 2001. The Quaternary and Pliocene Yellowstone Plateau volcanic field of Wyoming, Idaho, and Montana. U.S. Geological Survey Professional Paper 729-G. Reston, VA: U.S. Geological Survey (Geology of Yellowstone National Park).

Clifton CG, Walters CC, Simoneit BRT. 1990. Hydrothermal petroleums from Yellowstone National Park, Wyoming, U.S.A. Applied Geochemistry 5(1-2):169-191. doi: 10.1016/ 0883-2927(90)90047-9.

Cook AC, Hainsworth LJ, Sorey ML, Evans WC, Southon JR. 2001. Radiocarbon studies of plant leaves and tree rings from Mammoth Mountain, CA: a long-term record of magmatic $\mathrm{CO}_{2}$ release. Chemical Geology 177(1-2): 117-131. doi: 10.1016/S0009-2541(00)00386-7.

Craig H. 1963. The isotopic geochemistry of water and carbon in geothermal areas. In: Tongiorgo E, editor. Proceedings of the Conference on Nuclear Geology in Geothermal Areas, Spoleto 1963.

de Vries HL, Barendsen GW. 1954. Measurements of age by the carbon-14 technique. Nature. 174(4442):1138-1141. doi: 10.1038/1741138a0.

Doher LI. 1980. Palynomorph preparation procedures currently used in the paleontology and stratigraphy laboratories, U.S. Geological Survey: U.S. Dept. of the Interior, Geological Survey, Circular USGS Numbered Series 830, http://pubs.er.usgs.gov/publication/cir830 (accessed September 2018).

Egan J, Staff R, Blackford J. 2015. A high-precision age estimate of the Holocene Plinian eruption of Mount Mazama, Oregon, USA. The Holocene. 25(7):1054-1067. doi: 10.1177/ 0959683615576230.

Evans WC, Bergfeld D, McGeehin JP, King JC, Heasler H. 2010. Tree-ring ${ }^{14} \mathrm{C}$ links seismic swarm to $\mathrm{CO} 2$ spike at Yellowstone, USA. Geology 38(12):1075-1078. doi: 10.1130/G31 345.1 .

Fletcher WJ, Zielhofer C, Mischke S, Bryant C, Xu X, Fink D. 2017. AMS radiocarbon dating of pollen concentrates in a karstic lake system. Quaternary Geochronology 39:112-123. doi: 10.1016/j. quageo.2017.02.006.

Friedman I. 1970. Some investigations of the deposition of travertine from Hot Springs - I. The isotopic chemistry of a travertine-depositing spring. Geochimica et Cosmochimica Acta 34:1303-1315.

Higuera PE, Whitlock C, Gage JA. 2010. Linking tree-ring and sediment-charcoal records to reconstruct fire occurrence and area burned in subalpine forests of Yellowstone National Park, USA. The Holocene 21(2):327-341. doi: 10. 1177/0959683610374882.

Howarth JD, Fitzsimons SJ, Jacobsen GE, Vandergoes MJ, Norris RJ. 2013. Identifying a reliable target fraction for radiocarbon dating sedimentary records from lakes. Quaternary Geochronology 17:68-80. doi: 10.1016/j.quageo. 2013.02.001.

Hua Q, Barbetti M, Rakowski AZ. 2013. Atmospheric radiocarbon for the period 1950-2010. Radiocarbon 55(4):2059-2072. doi: 10.2458/azu_js_rc.v55i2.16177.

Jensen BL, Beaudoin AB. 2016. Geochemical characterization of tephra deposits at archeological and paleoenvironmental sites across south-central Alberta and Saskatchewan; Archeological Survey of Alberta. Occasional Paper 36:154-160.

Johnson SY, Stephenson WJ, Morgan LA, Shanks WC, Pierce KL. 2003. Hydrothermal and tectonic activity in northern Yellowstone Lake, Wyoming. Geological Society of America Bulletin 115(8):954-971. doi: 10.1130/B25111.1. 
Jones MD. 2004. High-resolution records of climate change from lacustrine stable isotopes through the last two millennia in Western Turkey [PhD thesis]. Plymouth, UK: University of Plymouth.

Kampstra. 2008. Beanplot: A boxplot alternative for visual comparison of distributions. Journal of Statistical Software, Code Snippets 28(1):1-9.

Kelts K, Briegel U, Ghilardi K, Hsu K. 1986. The limnogeology-ETH coring system. Swiss Journal of Hydrology 48(1):104-115. doi: 10.1007/ BF02544119.

Krause TR, Whitlock C. 2013. Climate and vegetation change during the late-glacial/earlyHolocene transition inferred from multiple proxy records from Blacktail Pond, Yellowstone National Park, USA. Quaternary Research 79(03):391-402. doi: 10.1016/j.yqres.2013.01.005.

Krause TR, Lu Y, Whitlock C, Fritz SC, Pierce KL. 2015. Patterns of terrestrial and limnologic development in the northern Greater Yellowstone Ecosystem (USA) during the late-glacial/earlyHolocene transition. Palaeogeography, Palaeoclimatology, Palaeoecology 422:46-56. doi: 10.1016/j.palaeo.2014.12.018.

Kuehn SC, Froese DG, Carrara PE, Foit FF, Pearce NJG, Rotheisler P. 2009. Major- and traceelement characterization, expanded distribution, and a new chronology for the latest Pleistocene Glacier Peak tephras in western North America. Quaternary Research 71(02):201-216. doi: 10. 1016/j.yqres.2008.11.003.

Lewicki JL, Hilley GE. 2014. Multi-scale observations of the variability of magmatic $\mathrm{CO}_{2}$ emissions, Mammoth Mountain, CA, USA. Journal of Volcanology and Geothermal Research 284:1-15. doi: 10.1016/j.jvolgeores. 2014.07.011.

Licciardi JM, Pierce KL. 2018. History and dynamics of the Greater Yellowstone Glacial System during the last two glaciations. Quaternary Science Reviews 200:1-33. doi: 10.1016/j.quascirev.2018. 08.027.

Long A, Davis OK, Lanois JD. 1992. Separation and ${ }^{14} \mathrm{C}$ Dating of pure pollen from lake sediments: nanofossil AMS dating: Radiocarbon 34: 557-560. doi: 10.1017/S0033822200051110.

Love JD, Good JM. 1970. Hydrocarbons in thermal areas, northwestern Wyoming. U.S. Geological Survey Professional Paper 644-B.

Love JD, Good JM, Browne DG. 2007. Reconnaissance study of Pleistocene and fluvial deposits in and near ancestral Yellowstone Lake, Wyoming. In: Morgan LA, editor. Integrated geoscience studies in the greater Yellowstone area-volcanic, tectonic, and hydrothermal processes in the Yellowstone geoecosystem. U.S. Geological Survey Professional Paper 1717.

Lu Y, Fritz SC, Stone JR, Krause TR, Whitlock C, Brown ET, Benes JV. 2017. Trends in catchment processes and lake evolution during the late-glacial and early- to mid-Holocene inferred from high-resolution XRF data in the Yellowstone region. Journal of Paleolimnology 58(4):551-569. doi: 10.1007/s10933-017-9991-x.

Matthews NE, Vazquez JA, Calvert AT. 2015. Age of the Lava Creek supereruption and magma chamber assembly at Yellowstone based on $40 \mathrm{Ar} / 39 \mathrm{Ar}$ and $\mathrm{U}-\mathrm{Pb}$ dating of sanidine and zircon crystals: Age of the Lava Creek Supereruption. Geochemistry, Geophysics, Geosystems 16(8):2508-2528. doi: 10.1002/ 2015GC005881.

McNichol AP, Osborne EA, Gagnon AR, Fry B, Jones GA. 1994. TIC, TOC, DIC, DOC, PIC, POC - unique aspects in the preparation of oceanographic samples for ${ }^{14} \mathrm{C}$-AMS. Nuclear Instruments and Methods in Physics Research Section B: Beam Interactions with Materials and Atoms 92(1-4):162-165. doi: 10.1016/0168583X(94)95998-6.

Mensing SA, Southon JR. 1999. A simple method to separate pollen for AMS radiocarbon dating and its application to lacustrine and marine sediments. Radiocarbon 41:1-8. doi: 10.1017/ S0033822200019287.

Morgan LA, Shanks WC III, Pierce KL, Lovalvo DA, Lee GK, Webring MW, Stephenson WJ, Johnson SY, Harlan SS, Schulze B, Finn CA. 2007. The floor of Yellowstone Lake is anything but quiet-new discoveries from highresolution sonar imaging, seismic-reflection profiling, and submersible studies. In: Morgan LA, editor. Integrated geoscience studies in the greater Yellowstone area-volcanic, tectonic, and hydrothermal processes in the Yellowstone geoecosystem. U.S. Geological Survey Professional Paper 1717.

Morgan LA, Shanks WC, Pierce KL. 2009. Hydrothermal processes above the Yellowstone magma chamber: large hydrothermal systems and large hydrothermal explosions. Geological Society of America Special Paper 459.

Nanavati WP, Whitlock C, Iglesias V, de Porras ME. 2019. Postglacial vegetation, fire, and climate history along the eastern Andes, Argentina and Chile (lat. $41-55^{\circ} \mathrm{S}$ ). Quaternary Science Reviews 207:145-160. doi: 10.1016/j.quascirev. 2019.01.014.

Neulieb T, Levac E, Southon J, Lewis M, Pendea IF, Chmura GL. 2013. Potential pitfalls of pollen dating. Radiocarbon 55:1142-1155.

Newnham RM, Vandergoes MJ, Garnett MH, Lowe DJ, Prior C, Almond PC. 2007. Test of AMS ${ }^{14} \mathrm{C}$ dating of pollen concentrates using tephrochronology. Journal of Quaternary Science 22:37-51. doi: 10.1002/jqs.1016.

Pasquier-Cardin A, Allard P, Ferreira T, Hatte C, Coutinho R, Fontugne M, Jaudon M. 1999. Magma-derived $\mathrm{CO}_{2}$ emissions recorded in ${ }^{14} \mathrm{C}$ and ${ }^{13} \mathrm{C}$ content of plants growing in Furnas caldera, Azores. Journal of Volcanology and 
Geothermal Research 92(1):195-207. doi: 10. 1016/S0377-0273(99)00076-1.

Pierce KL, Cannon KP, Meyer GA, Trebesch MJ, Watts RD. 2007. Postglacial inflation-deflation cycles, tilting, and faulting in the yellowstone caldera based on Yellowstone Lake shorelines. In: Morgan LA, editor. Integrated geoscience studies in the greater Yellowstone areavolcanic, tectonic, and hydrothermal processes in the Yellowstone geoecosystem. U.S. Geological Survey Professional Paper 1717.

Regnéll J. 1992. Preparing pollen concentrates for AMS dating - a methodological study from a hard-water lake in southern Sweden. Boreas 21:373-377. doi: 10.1111/j.1502-3885.1992.tb00042.x.

Reimer PJ, Reimer R. 2004. CALIBomb radiocarbon calibration at http://calib.qub.ac.uk/CALIBomb/.

Reimer PJ, Brown TA, Reimer RW. 2004. Reporting and calibration of post-bomb ${ }^{14} \mathrm{C}$ data. Radiocarbon 46(3):1299-1304.

Reimer PJ, Bard E, Bayliss A, Beck JW, Blackwell PG, Ramsey CB, Buck CE, Cheng H, Edwards RL, Friedrich M, Grootes PM, Guilderson TP, Haflidason H, Hajdas I, Hatté C, Heaton TJ, Hoffmann DL, Hogg AG, Hughen KA, Kaiser KF, Kromer B, Manning SW, Niu M, Reimer RW, Richards DA, Scott EM, Southon JR, Staff RA, Turney CSM, van der Plicht J. 2013. IntCal13 and Marine13 radiocarbon age calibration curves $0-50,000$ years cal BP. Radiocarbon 55(4):1869-1887. doi: 10.2458/ azu_js_rc.55.16947.

Richardson F, Hall VA. 1994. Pollen concentrate preparation from highly organic Holocene peat and lake deposits for AMS dating 1. Radiocarbon 36:407-412. doi: 10.1017/ S0033822200014582.

Roberts ML, Elder KL, Jenkins WJ, Gagnon AR, Xu L, Hlavenka JD, Longworth BE. 2019. ${ }^{14} \mathrm{C}$ Blank corrections for 25-100 $\mu$ g samples at the National Ocean Sciences AMS Laboratory. Radiocarbon 61(5):1403-1411. doi: 10.1017/RDC.2019.74.

Roberts N, Reed JM, Leng MJ, Kuzucuoğlu C, Fontugne M, Bertaux J, Woldring H, Bottema S, Black S, Hunt E, et al. 2001. The tempo of Holocene climatic change in the eastern Mediterranean region: new high-resolution crater-lake sediment data from central Turkey. The Holocene 11(6):721-736. doi: 10.1191/ 09596830195744.

Romme WH, Despain DG. 1989. Historical perspective on the Yellowstone fires of 1988. BioScience 39(10):695-699. doi: 10.2307/1311000.

Shanks WC III, Alt JC, Morgan LA. 2007. Geochemistry of sublacustrine hydrothermal deposits in Yellowstone Lake-hydrothermal reactions, stable-isotope systematics, sinter deposition, and spire formation. In: Morgan LA, editor. Integrated geoscience studies in the greater Yellowstone area-volcanic, tectonic, and hydrothermal processes in the Yellowstone geoecosystem. U.S. Geological Survey Professional Paper 1717.

Smith BN, Epstein S. 1971. Two categories of ${ }^{13} \mathrm{C} /{ }^{12} \mathrm{C}$ ratios for higher plants. Plant Physiology 47(5):380-384. doi: 10.1104/pp.47.3.380.

Stuiver M, Reimer PJ, Reimer RW. 2019. CALIB 7.1 [WWW program] at http://calib.org.

Tennant RK, Jones RT, Brock F, Cook C, Turney CSM, Love J, Lee R. 2013. A new flow cytometry method enabling rapid purification of fossil pollen from terrestrial sediments for AMS radiocarbon dating: Journal of Quaternary Science 28:229-236. doi: 10.1002/jqs.2606.

Theriot EC, Fritz SC, Whitlock C, Conley DJ. 2006. Late Quaternary rapid morphological evolution of an endemic diatom in Yellowstone Lake, Wyoming. Paleobiology 32(1):38-54. doi: 10 . 1666/02075.1.

Tiller CC. 1995. Postglacial sediment stratigraphy of large lakes in Greater Yellowstone: scenarios of tectonic and climatic forcing [MS thesis]. Minneapolis (MN): University of Minnesota.

Tweddle JC, Edwards KJ. 2010. Pollen preservation zones as an interpretative tool in Holocene palynology. Review of Palaeobotany and Palynology 161(1-2):59-76. doi: 10.1016/j. revpalbo.2010.03.004.

U.S. Geological Survey. 1972. Geologic map of Yellowstone National Park. U.S. Geological Survey Miscellaneous Geologic Investigations I-711. 1:125,000.

Vandergoes MJ, Prior CA. 2003. AMS dating of pollen concentrates - a methodological study of Late Quaternary Sediments from South Westland, New Zealand. Radiocarbon 45: 479-491. doi: 10.1017/S0033822200032823.

Vaughan RG, Heasler H, Jaworowski C, Lowenstern JB, Keszthelyi LP. 2014. Provisional maps of thermal areas in Yellowstone National Park, based on satellite thermal infrared imaging and field observations. U.S. Geological Survey Scientific Investigations Report 2014-5137.

Werner C, Brantley S. 2003. $\mathrm{CO}_{2}$ emissions from the Yellowstone volcanic system: Yellowstone $\mathrm{CO}_{2}$ emissions. Geochemistry, Geophysics, Geosystems 4(7). doi: 10.1029/2002GC000473. [accessed 2018 Aug 14]. http://doi.wiley.com/10. 1029/2002GC000473.

Whitlock C. 1993. Postglacial vegetation and climate of Grand Teton and southern Yellowstone National Parks. Ecological Monographs 63(2):173-198. doi: 10.2307/2937179.

Whitlock C, Bartlein PJ, Van Norman KJ. 1995. Stability of Holocene climate regimes in the Yellowstone Region. Quaternary Research 43(3):433-436. doi: 10.1006/qres.1995.1049.

Wotzlaw J-F, Bindeman IN, Stern RA, D'Abzac F-X, Schaltegger U. 2015. Rapid heterogeneous assembly of multiple magma reservoirs prior to Yellowstone supereruptions. Scientific Reports 5(1):1-10. doi: 10.1038/srep14026. 
Zdanowicz CM, Zielinski GA, Germani MS. 1999. Mount Mazama eruption: Calendrical age verified and atmospheric impact assessed. Geology 27(7):621-624. doi: 10.1130/00917613(1999)0272.3.CO;2.

Zhang J-F, Xu B, Turner F, Zhou L, Gao P, Lü X, Nesje A. 2017. Long-term glacier melt fluctuations over the past $2500 \mathrm{yr}$ in monsoonal
High Asia revealed by radiocarbon-dated lacustrine pollen concentrates. Geology 45(4):359-362. doi: 10.1130/G38690.1.

Zimmerman SRH, Brown TA, Hassel C, Heck J. 2019. Testing pollen sorted by flow cytometry as the basis for high-resolution lacustrine chronologies. Radiocarbon 61:359-374. doi: 10 . 1017/RDC.2018.89. 